\title{
DETECTION OF CLOSTRIDIUM PERFRINGENS ENTEROTOXIN BY TISSUE CULTURE AND DOUBLE-GEL DIFFUSION METHODS
}

\author{
L. G. Giugliano, M. F. Stringer* and B. S. Drasar
}

Department of Medical Microbiology, London School of Hygiene and Tropical Medicine, Keppel Street, London WC1E 7HT and *Food Hygiene Laboratory, Central Public Health Laboratory, 175 Colindale Avenue, London NW9 5HT

\begin{abstract}
SUMMARY. Culture filtrates of four enterotoxin-producing strains of Clostridium perfringens type A produced morphological changes in cells of 10 of 12 established mammalian cell lines tested, and particularly Vero (African green-monkey kidney) and MDCK (dog kidney) cells. Double-gel diffusion and Vero-cell tests detected enterotoxin in culture filtrates of, respectively, $29(28 \%)$ and $56(54 \%)$ of 103 strains of $C$. perfringens tested. The feasibility of cell-culture assays for the routine detection of $C$. perfringens enterotoxin is indicated.
\end{abstract}

\section{INTRODUCTION}

An enterotoxin has been shown to be responsible for the typical symptoms of clostridial food poisoning. Ingestion of large numbers of vegetative Clostridium perfringens cells in food is followed by their multiplication and sporulation in the intestine and by production of enterotoxin (Collee, 1974).

Methods used for the detection of enterotoxin include biological tests with animals or human volunteers, and serological tests with specific antiserum prepared against purified enterotoxin. The use of tissue culture methods has been confined mainly to studies of the mode of action of $C$. perfringens enterotoxin. Thus, Giger and Pariza (1978) used cultured rat hepatocytes and McClane and McDonel (1979) African green-monkey kidney (Vero) cells for this purpose. Subsequent reports of the use of the Vero-cell assay as a highly sensitive technique for the assay of $C$. perfringens enterotoxin have been presented (McDonel and McClane, 1981).

In the present study, the effect of $C$. perfringens enterotoxin on different mammalian cell lines was determined and the detection of $C$. perfringens enterotoxin by double-gel diffusion and tissue-culture assays compared.

\section{MATERIALS AND METHODS}

Bacterial strains. The strains used to study the sensitivity of different mammalian cell lines to enterotoxin were four enterotoxigenic strains of $C$. perfringens type A, serotype 41 (nos. $3663 / 73,4246 / 76,4457 / 76$ and $4873 / 76$ ), isolated from food-poisoning outbreaks, and a control, non-enterotoxigenic strain of $C$. perfringens type A (no. 258/80), isolated from a patient after septic delivery; they were obtained from the collection of the Food Hygiene Laboratory, Central Public Health Laboratory, Colindale Avenue, London NW9 5HT.

Another 103 strains of $C$. perfringens type A were used in tests comparing double-gel diffusion and tissue-culture methods for the detection of enterotoxin; 85 strains had been isolated from the faeces of patients or from food implicated in different outbreaks of food poisoning and 18 strains were from other sources such as the faeces of healthy persons, food and diverse clinical specimens.

Growth conditions and enterotoxin production. Stock cultures of the strains used in the study of the sensitivity of mammalian cell lines to enterotoxin were subcultured to $20 \mathrm{ml}$ of 
fluid-thioglycollate medium (BBL, Cockeysville, MD, USA), heat-shocked at $75^{\circ} \mathrm{C}$ for $20 \mathrm{~min}$, and incubated overnight at $37^{\circ} \mathrm{C}$. An inoculum $(0.2 \mathrm{ml})$ from the overnight culture was transferred to freshly-steamed fluid-thioglycollate medium $(20 \mathrm{ml})$ and incubated for $6 \mathrm{~h}$ at $37^{\circ} \mathrm{C}$. An inoculum ( $200 \mu \mathrm{l})$ of the 6-h culture was transferred to $20 \mathrm{ml}$ of modified Duncan and Strong medium (DS/R; Labbe and Rey, 1979), and incubated at $37^{\circ} \mathrm{C}$ for $18-20 \mathrm{~h}$. DS/R cultures were centrifuged $(3000 \mathrm{~g}$ for $20 \mathrm{~min}$ ) and supernates filtered through membrane filters (pore size 0.22 $\mu \mathrm{m}$; Millipore Corp., Bedford, MA, USA). Portions $(0.5 \mathrm{ml})$ of the filtrates were stored at $-70^{\circ} \mathrm{C}$.

Similar procedures were followed for the culture of the 103 strains used in the comparative study of serological and tissue-culture assays, except that the sporulation medium of Tsai, Torres-Anjel and Riemann (1974) was used, with raffinose instead of starch (TTR/R). Enterotoxin production was better in TTR/R medium than in DS/R medium used in preliminary studies. Spores were enumerated by the method of Duncan and Strong (1968).

Cell culture. The 12 established mammalian cell lines used were: Chinese-hamster ovary (CHO-K1); baby-hamster kidney (BHK); mouse areolar and adipose tissue (L-929); mouse adrenal-cortex tumour (Y-1); African green-monkey kidney (Vero); adult Rhesus-monkey kidney (LLC-MK 2 ); rabbit kidney (RK-13); dog kidney (MDCK); human embryonic intestine (INT-407); human embryonic foreskin (HFS); human embryonic lung (MRC-5); and human cervical carcinoma (HeLa). The cell lines, their growth and maintenance have been described previously (Giugliano, Mann and Drasar, 1982).

Toxin assay. Toxin assays were performed as described by Giugliano et al. (1982). Thus, serial twofold dilutions of sterile bacterial filtrates added to freshly seeded cells in microtitre plates (Falcon, Microtest II, Becton Dickinson and Co., Cockeysville, MD, USA) were incubated at $37^{\circ} \mathrm{C}$. Cells were examined microscopically after incubation for 18-20, 48 and 72 h. Any observed effects on cell growth and morphology were scored in arbitrary units, 0, 1, 2, 3 and 4 , corresponding, respectively, to $c .0,25,50,75$ or $90 \%$ of cells with abnormal appearance. The titre of enterotoxin in filtrates was taken as the highest dilution giving a $50 \%$ end-point, calculated, if necessary, by interpolation.

Double gel diffusion. The technique, a modification of that described by Casman et al. (1969), has been described by Stringer, Watson and Gilbert (1982). Undiluted filtrates were tested in gel tests.

Neutralisation tests. Purified enterotoxin and specific anti-enterotoxin serum, kindly provided by Dr R. Skjelkväle (Norwegian Food Research Institute, Oslo, Norway), were used in neutralisation tests. Equal volumes of culture filtrate, or purified enterotoxin, and anti-enterotoxin serum (at a dilution of 1 in 30 ) were incubated at $37^{\circ} \mathrm{C}$ for $30 \mathrm{~min}$, and $25-\mu \mathrm{l}$ amounts of the mixture added to the previously described cells.

\section{Results}

\section{Activity of $C$. perfringens filtrates on cell lines}

Culture filtrates of toxigenic $C$. perfringens strains 3663/73, 4246/76, 4457/76 and 4873/76 caused changes in cell morphology of 10 of the 12 mammalian cell lines studied; the effect was completely neutralised by specific anti-enterotoxin serum. Neither filtrates of these toxigenic strains nor purified enterotoxin were cytotoxic for the cell lines CHO-K 1 and Y-1. Although the titre of the toxin detected depended upon the strain tested, the pattern of sensitivity with the cell lines was constant. Vero and MDCK cells were the most sensitive; INT-407, BHK, HeLa and RK-13 cells were of intermediate sensitivity; and LLC-MK 2, L-929, MRC-5 and HFS cells were least sensitive. The minimum concentration of enterotoxin detected when dilutions of purified enterotoxin were incubated with Vero cells was $0.04 \mu \mathrm{g} / \mathrm{ml}$; with the double-gel diffusion technique, it was $0.5 \mu \mathrm{g} / \mathrm{ml}$.

Whereas culture filtrate from the non-enterotoxigenic strain $258 / 80$ of $C$. perfringens did not affect the morphology of the cells, enterotoxic filtrates caused detachment and rounding up of the cells of all sensitive lines (fig. 1). The effect with Vero and MDCK cells was observed within $1-1.5 \mathrm{~h}$, increasing with further incubation up to $18-24 \mathrm{~h}$; the latter incubation time was used in the standard Vero-cell assay. With the other sensitive cell lines, incubation for more than $4 \mathrm{~h}$ was required before the effect appeared with the maximum effect obtained only after $24 \mathrm{~h}$. 

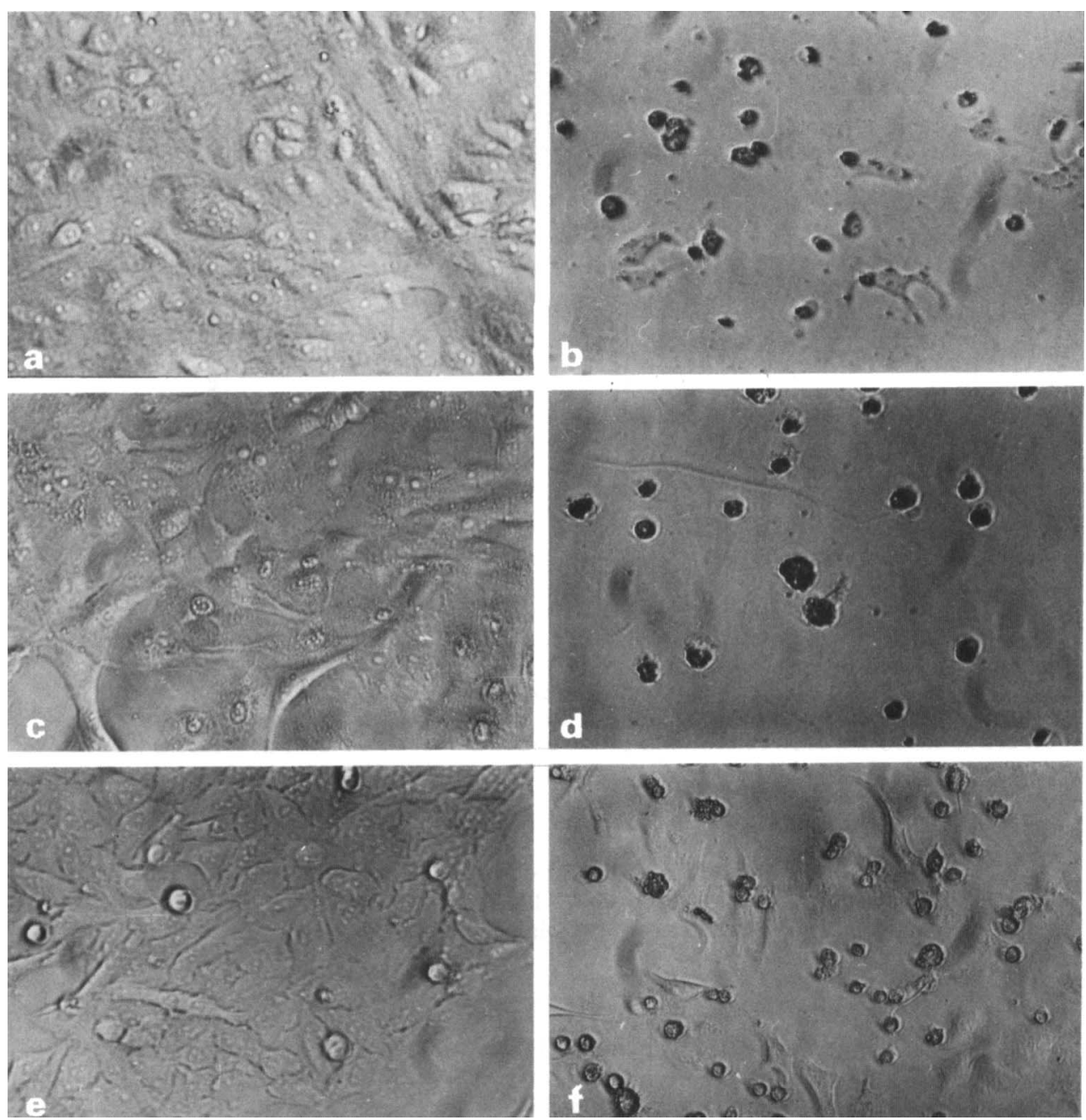

Fig. 1.-Vero (A, B), MDCK (C, D) and HeLa (E, F) cells after incubation with culture filtrate from non-enterotoxigenic (left) or enterotoxigenic (right) strain of Clostridium perfringens. Magnification $\times 50$.

Comparison of double-gel diffusion and Vero-cell assays

Filtrates of 103 strains of $C$. perfringens grown in sporulation medium TTR/R were assayed by both Vero-cell and double-gel diffusion methods. Enterotoxin was detected in filtrates of 29 $(28 \%)$ strains by double-gel diffusion and in filtrates of $56(54 \%)$ strains by Vero-cell assay. Because the 85 food-poisoning strains were the epidemiologically and serologically confirmed agents in episodes of food-borne illness, it might seem reasonable to assume that they would have produced enterotoxin in vitro. However, only 48 of the strains examined produced $>10^{5}$ spores/ml in TTR/R sporulation medium; it was not surprising, therefore, to find that most of the remaining 37 filtrates did not contain detectable enterotoxin. Of the 48 filtrates from the sporulating strains, $21(43 \%)$ were found to be enterotoxin-positive by double-gel diffusion, whereas $37(77 \%)$ were positive by the Vero-cell assay. Tests were generally positive in double-gel diffusion tests with those filtrates that had given high titres in the Vero-cell assay. 


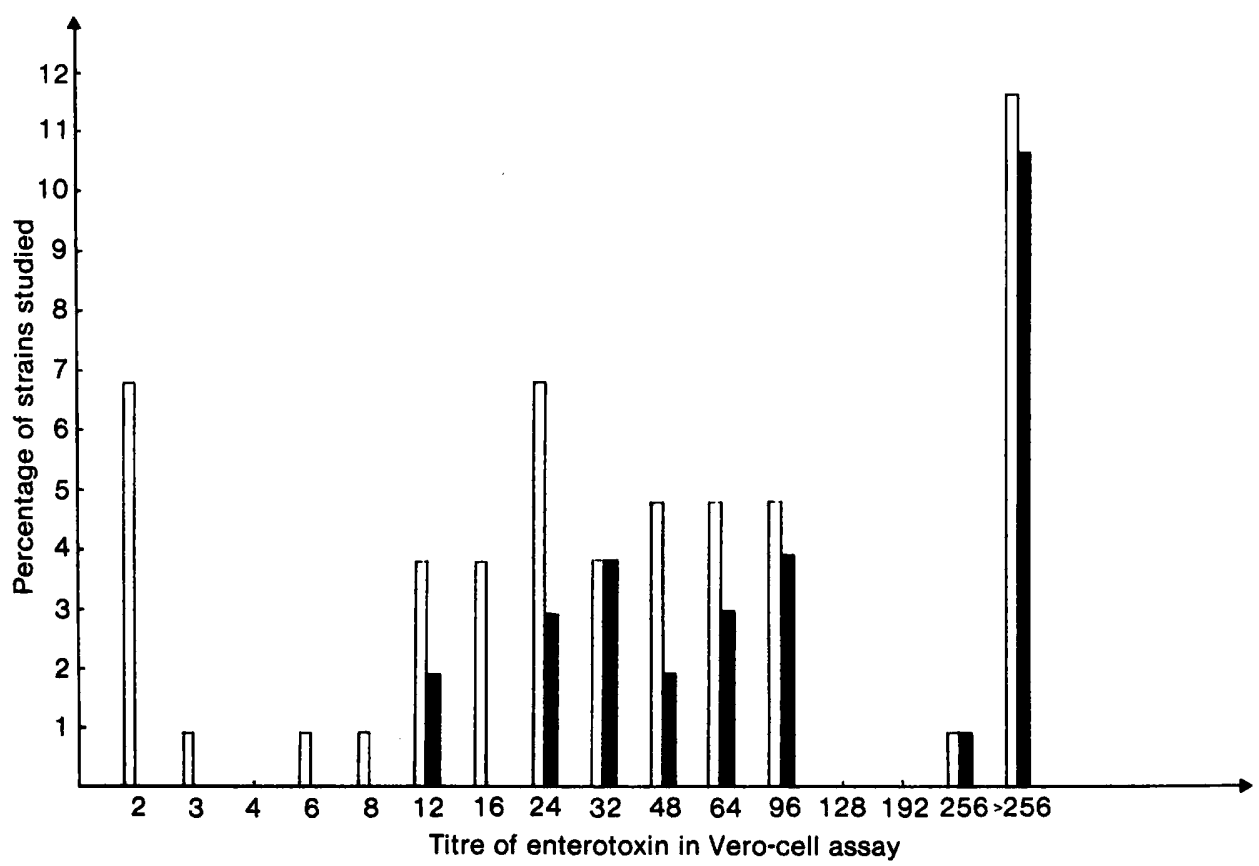

FIG. 2.-Distribution of 56 enterotoxin-producing strains of Clostridium perfringens with titre of enterotoxin detected by Vero-cell assay, $\square$; filtrates scored positive by double-gel diffusion test are shown, $\mathbf{}$.

The sensitivity of the Vero-cell assay for the detection of enterotoxin at each dilution tested was greater than that of double-gel diffusion. The distribution of strains in which enterotoxin was detected by either Vero-cell assay or double-gel diffusion is shown in fig. 2.

\section{Discussion}

C. perfringens enterotoxin has been detected by several whole animal assays measuring, for example, erythemal activity, mouse lethality and dilation of rabbit ligated-ileal loop. The minimum concentration of enterotoxin detected in the most sensitive animal assays is $c$. 1.25-2.5 $\mu \mathrm{g} / \mathrm{ml}$ but the methods are costly and difficult to standardise. Serological assays, therefore, have superseded animal assays for the detection of enterotoxin and are the methods of choice. Techniques such as single-gel diffusion, double-gel diffusion, electroimmunodiffusion and counterimmunoelectrophoresis, though less sensitive than Vero-cell assay, detect minimum concentrations of enterotoxin in the range $0.2-2.0 \mu \mathrm{g} / \mathrm{ml}$ (Stringer et al., 1982), and reverse passive haemagglutination and radioimmunoassay have been reported to detect as little as 0.001 $\mu \mathrm{g}$ of enterotoxin per ml. Serological methods, however, lack the functional application of specific biological assays. Vero cells (McClane and McDonel, 1979; McDonel and McClane, 1981) and HeLa cells (Keusch and Donta, 1975) were the only two established cell lines previously known to be sensitive to $C$. perfringens enterotoxin. In this study, a further eight established cell lines susceptible to $C$. perfringens enterotoxin are reported. Comparison of the Vero-cell and double-gel diffusion assays indicated the feasibility of cell-culture systems for the routine detection of enterotoxin, and showed that the Vero-cell assay was simple, efficient and 12 times more sensitive than double-gel diffusion for enterotoxin detection.

Our assay of the direct toxigenicity of culture filtrates of $C$. perfringens on Vero cells and the Vero-cell plating efficiency assay of McDonel and McClane (1981) reflect the same innate properties of these cells. Our assay, however, is more easily performed, more readily standardised and, hence, more readily adapted for routine use. 
The faeces of patients with $C$. perfringens food poisoning may contain 3-16 $\mu \mathrm{g}$ of enterotoxin per gram of faeces (Skjelkväle and Uemura, 1977), a range within which the Vero-cell assay might be expected to detect enterotoxin directly in faeces. However, for that purpose, specific serum neutralisation of the cytopathic response would be needed to exclude the possibility that other sources in faeces or food had caused the cytopathic effects. Detection of $C$. difficile toxin in faeces by tissue culture assay has been reported recently (Gilligan, McCarthy and Genta, 1981).

\section{REFERENCES}

Casman, E. P., Bennett, R. W., Dorsey, A. E. and Stone, J. E. 1969. The micro-slide gel double diffusion test for the detection and assay of staphylococcal enterotoxins. Health Laboratory Science, 6, 185-198.

ColleE, J. G. 1974. Clostridium perfringens ( $\mathrm{Cl}$. welchii) in the human gastro-intestinal tract. In The normal microbial flora of man, edited by F. A. Skinner and J. G. Carr, Academic Press, London, pp. 205-219.

DunCAN, C. L. AND Stong, D. H. 1968. Improved medium for sporulation of Clostridium perfringens. Applied Microbiology, 16, 82-89.

Giger, O. AND ParizA, M. W. 1978. Depression of amino-acid transport in cultured rat hepatocytes by purified enterotoxin from Clostridium perfringens. Biochemical and Biophysical Research Communications, 82, 378-383.

Gilligan, P. H., MCCarThy, L. R. AND Genta, V. M. 1981. Relative frequency of Clostridium difficile in patients with diarrheal disease. Journal of Clinical Microbiology, 14, 26-31.

Giugliano, L. G., ManN, G. F. AND Drasar, B. S. 1982. The response of mammalian cell lines to toxins produced by Escherichia coli. Journal of Medical Microbiology, 15, 531-539.

KeUSCH, G. T. AND DonTA, S. T. 1975. Classification of enterotoxins on the basis of activity in cell culture. Journal of Infectious Diseases, 131, 58-63.

LABBE, R. G. AND REY, D. K. 1979. Raffinose increases sporulation and enterotoxin production by Clostridium perfringens type A. Applied and Environmental Microbiology, 37, 1196-1200.

MCClane, B. A. AND MCDonel, J. L. 1979. The effects of Clostridium perfringens enterotoxin on morphology, viability and macromolecular synthesis in Vero cells. Journal of Cellular Physiology, 99, 191-199.

MCDONEL, J. L. AND MCCLANE, B. A. 1981. Highly sensitive assay for Clostridium perfringens enterotoxin that uses inhibition of plating efficiency of Vero cells grown in culture. Journal of Clinical Microbiology, 13, 940-946.

SkJELKVÄLE, R. AND UemURA, T. 1977. Detection of enterotoxin in faeces and anti-enterotoxin in serum after Clostridium perfringens food poisoning. Journal of Applied Bacteriology, 32, 355-363.

Stringer, M. F., Watson, G. N. AND Gilbert, R. J. 1982. Clostridium perfringens type A: Serological typing and methods for the detection of enterotoxin. In: Isolation and identification methods for food poisoning organisms, edited by J. E. L. Corry, D. Roberts and F. A. Skinner. Society for Applied Bacteriology Technical Series, No. 17, Academic Press, London, pp. 111-135.

TSAI, C. C., ToRres-ANJEL, M. J. AND RIEMANN, H. P. 1974. Improved culture techniques and sporulation medium for enterotoxin production by Clostridium perfringens type A. Journal of the Formosan Medical Association, 73, 404-409. 